\title{
Farmer adaptation strategy in paddy fields affected by climate variability in monsoon regions
}

\author{
YAYAN APRIYANA ${ }^{\vee}$, YELI SARVINA, ELSA RAKHMI DEWI, ARIS PRAMUDIA \\ Indonesian Agroclimate and Hydrology Research Institute. Jl. Tentara Pelajar No. 1A PO. BOX. 830. Kampus Penelitian Pertanian Cimanggu, Bogor \\ 16111, West Java, Indonesia. Tel.: +62-251-8312760, Fax.: +62-251-8323909, `email: yanapri@yahoo.com
}

Manuscript received: 23 March 2017. Revision accepted: 15 June 2017.

\begin{abstract}
Apriyana Y, Sarvina Y, Dewi ER, Pramudia A. 2017. Farmer adaptation strategy in paddy field affected by climate variability in monsoon regions. Asian J Agric 1: 9-16. One of the strategies to minimize the impacts of climate variability and climate anomalies on paddy fields in monsoon regions is the adaptation of agriculture cultivation. It is important to minimize the impact of these two phenomena to reduce economic loss, particularly for food security in Indonesia. The objectives of this study are: (i) to identify onset and cropping pattern in irrigated land, rainfed and dry land in affected areas due to climate anomalies, (ii) to collect information on carr ying capacity water resources and adaptation practices applied by farmers and, (iii) to identify strategies for farmers on irrigated land, rainfed and dry land in the region affected by climate variability. The desk work analysis and field survey were conducted in Serang district, Banten Province, Subang district, West Java Province and Pati district, Central Jawa Province, Indonesia. The study was undertaken in three cluster activities i.e. (i) correlation analysis of climate anomalies and rainfall, (ii) field survey and, (iii) analys is of onset planting season, cropping pattern, water availability, the best planting time and irrigation schedule. The results showed that the farmers in affected areas due to climate variability could adapt by shifting the onset of planting season. Farmers in irrigated lands changed their onset around 2-4 ten-days period to October II - December II. Furthermore, in rainfed areas, the onset around 4-6 ten-days period was shifted to November I - January III. For dryland their onset around 6-8 ten-days period was moved to November II - February I. The cropping pattern rice-rice-palawija/fallow was applied on irrigated land. Furthermore, the pattern of rice-rice/palawija/fallow-fallow was carried out in rainfed. Finally, the pattern of palawija-palawija/fallow-dormant was performed on the dry land. Adaptation programs dealing with climate variability in Serang and Pati districts varied more than in Subang district. In Serang and Pati, during the first planting season, farmers applied irrigation from approximately 20\%-30\% water pump from the river and during second planting season, farmers in Pati district used water from a well-pump, as well as in Serang that can reach $100 \%$ of the application.
\end{abstract}

Keywords: Farmer adaptation strategy, climate variability, paddy field, monsoon regions

\section{INTRODUCTION}

Climate variability and climate change are two phenomena of climate anomaly which has become a strategic issue and serious concern in Indonesia because it is believed to have a tremendous impact on life in various sectors and could have adverse impacts on global food production and food security (Apriyana 2011; Las et al. 2011). Climate variability in Indonesia driven by major inter-annual scales climate modes, such as the El Nino Southern Oscillation and Indian Ocean Dipole has been playing a vital role by often leading to droughts and decrease in crop yields (Ashok et al. 2001; D'Arrigo et al. 2006; Behera et al. 2008; Hansen et al. 2011)

The important strategy for Indonesian agriculture, especially for food crops, is a determination of planting season onset that is strongly related to climate anomalies (Naylor et al. 2001, 2007). Determination of onset is part of cropping calendar cultivation (Runtunuwu et al. 2007), and it has been traditionally developed by farmers for generations with a variety of different terms in each area (Koesmaryono et al. 2008). However, various indigenous knowledge cannot be fully used as a reference in determining the planting season onset due to climate change and finding indicators of season onset become more difficult. Rainfall fluctuation is very dynamic due to weather anomalies, and can cause a shift in the onset of rainy season and dry season. The impact of rainfall pattern alteration and a change of the season start caused alteration of planting date (Apriyana and Siburian 2014). Consequently, it is complicated for a farmer who has become accustomed to a particular cropping calendar.

In Indonesia, many farmers who are in a region with a monsoon climate, plant rice/paddy on a technical irrigation where water availability throughout the whole year, and there is an irrigation system flowing into the primary, secondary, and tertiary channel. Therefore, paddy cropping patterns in this area are more flexible than other rice fields. Other farmers plant the rice in fields with semi-technical irrigation, in which water availability is usually not enough for plant farming throughout the year. Another system of water supply for rice plantations is the rain-fed with water sources depending on rainfall. Paddy fields of this type are often found in areas of high altitude and dry land. The impacts of climate variability caused by El Niño and IOD were strongly felt in the region of irrigated land, rainfed, and dry land. These events could shift the planting start during the rainy season which was further delayed for 2-3 months in the next season (Las 2000). Planting time is also changing 10-20 days over the last decade (Linderholm. 2006). 
The fact that climate variability significantly influences Indonesian food security, shows the necessity to create strategic efforts and programs to anticipate climate variability impacts is very urgent and important. Adaptation of agriculture cultivation is expected to minimize the impact of these anomalies (Apriyana 2011).

To support the development of information system of integrated cropping calendar, it needs an assessment of adaptation strategy notably related to planting time and crop pattern for irrigated land, rain-fed and dry land. The objectives of this study were (i) to identify the farmer's strategy in irrigated land, rain-fed and dry land affected by climate anomalies, (ii) to arrange and interpret capacity of water resources and the farmers' adaptation practices and, (iii) to identify planting time and crop pattern practices.

\section{MATERIALS AND METHODS}

\section{Study area}

This study was conducted in three districts, i.e. (i) Serang district, Banten Province, (ii) Subang district, West Java Province and (ii) Pati district, Central Jawa Province, Indonesia. The study was conducted using desk work and field surveys.

\section{Analyses of climate anomaly and precipitation}

The study was performed by conducting several activities including rainfall, ENSO, DMI, onset of planting season, and sensitivity analysis as well as dynamic cropping pattern determination. Information on ENSO and IOD was obtained through web browsing. ENSO was represented by an index of Nino 3.4 and IOD indicated by DMI index. Precipitation anomaly was analyzed monthly for each station using a formula:

$$
\begin{aligned}
& A n o C H_{i j}=C H_{i j}-\overline{C H}_{i j} \\
& \overline{C H}_{i j}=\frac{i}{n} \sum_{j-1}^{n} C H_{j}
\end{aligned}
$$

Whereas:

$$
\begin{aligned}
& \text { AnoCH } \mathrm{CH}_{i j}=\text { rain fall anomaly for station }-\mathrm{i} \text {, month- } \mathrm{j} \\
& \mathrm{CH}_{i j}=\text { rain fall for station }-\mathrm{i} \text {, month }-\mathrm{j} \\
& \overline{C H}_{i j}=\text { rainfall average for station }-\mathrm{i} \text { and month }-\mathrm{j} \\
& \mathrm{n} \quad=\text { the number of data }
\end{aligned}
$$

Correlation analysis was performed temporally to identify the relationship between rainfall anomaly and SST anomaly as an indicator of climate anomaly for each month. The correlation was investigated for several periods: December-February; March-May; June-August and September-November using statistic software Minitab 14. Correlation value (r) was calculated with the equation below:

$$
r=\frac{n \sum_{i=1}^{n} x_{i} y_{i}-\left(\sum_{i=1}^{n} x i\right)\left(\sum_{i=1}^{n} y_{i}\right)}{\sqrt{\left[n \sum_{i=1}^{n} x_{i}^{2}-\left(\sum^{n} x_{i}\right)^{2}\right]\left[\left[n \sum_{i=1}^{n} y_{i}^{2}-\left(\sum^{n} y_{i}\right)^{2}\right]\right]}}
$$

Whereas:

$\mathrm{r}=$ Correlation value

$\mathrm{n}=$ Number of pair data

$\mathrm{x}=$ SST Nino 3.4 anomaly or IOD anomaly

$\mathrm{y}=$ Rainfall anomaly

Correlation value ranged between -1 to $1(-1 \geq \mathrm{r} \leq 1)$. The positive correlation means that the increasing $x$ value is followed by $y$ value and negative correlation means that increasing $\mathrm{x}$ value affect to decrease $\mathrm{y}$ value. Correlation was determined by confidence interval; strong (99\%), moderate $(95 \%)$ and weak $(90 \%)$. 18-years data length used in this study. The $r$ value is generated and adopted from http://faculty.vassar.edu/lowry/ch4apx.html i.e.(i) Strong $| \pm 0.54| \leq \mathrm{r}<| \pm 1.00|$; (ii) Moderate $\mid \pm$ $0.39|\leq \mathrm{r}<| \pm 0.54 \mid$; (iii) Weak $| \pm 0.33| \leq \mathrm{r}<| \pm 0.39|$; (iv) No correlation $r<| \pm 0.33|$.

The sea surface temperature (SST) Nino 3.4 (50N-50S, 1200-1700W) index was used to identify the influence ENSO on precipitation. The index was calculated by Kaplan Methods using season and monthly fluctuation. The value of SST Nino 3.4 was obtained from http://www.cpc.ncep.noaa.gov. Similar to ENSO, Dipole Mode (DM) or Indian Ocean Dipole (IOD) is represented by Dipole Mode Index (DMI). DMI represents differences between sea surface temperature in the West Indian Ocean $\left(50^{\circ}-70^{\circ} \mathrm{BT}, 10^{\circ} \mathrm{LU}-10^{\circ} \mathrm{LS}\right)$ and sea surface temperature in the Southeast Indian Ocean $\left(90^{\circ}-110^{\circ} \mathrm{BT}, 0^{\circ}-10^{\circ} \mathrm{LS}\right)$. The DMI data was adopted from http://www.jamstec.go.jp/frsgc/research/d1/iod. From all analyses, the lag dominant was identified using validation correlation for each station.

\section{Analysis of carrying capacity of water resources and farmers adaptation}

Both primary and secondary data were required in this study. The primary data was obtained from direct observation in the field either collected from questioner or observed data from the specific location. Moreover, the secondary data was collected from a literature study. To collect data and information, the field survey was conducted by interview methods. Sampling technique was applied to represent the population to minimize the gap (bias).

Farmers or farmer leader groups were decided as respondents. Five respondents were chosen for each land type represented in the district. Respondents were asked to have minimum ten years' experience in paddy/rice cultivation. Furthermore, to obtain more accurate data, the in-depth interview was performed through a questioner technique.

The steps of data collection are (i) identification of the characteristics of the target group of farmers, (ii) interrogator arrangement, (iii) tabulation of the descriptive data, (iv) survey data analysis, (v) data report. 


\section{Carrying capacity of water and climate resources}

The carrying capacity of water and climate resources was defined based on intrinsic values. This value was derived from the utilization of such resources. The carrying capacity was analyzed by using a sensitivity climate anomaly map (for the affected area or not) through inventory water and climate resources that affected cropping calendar dominantly and as unique characteristics for each zone. Carrying capacity of the environment and water resources were analyzed based on two approaches, namely the conditions of climate and water resources as well as its influence on the cropping calendar. The weather resources referred in this study are the intensity, pattern, and distribution of a ten-day period of rainfall. Whereas for water resources, some variables studied were the accessibility to water resources and the level of water availability. The accessibility to water resources was assessed based on: (i) the distance from the agriculture land to a water source, and (ii) the availability of tools to get the water. Furthermore, the level of water availability was accessed based on (i) the type of water source and (ii) Quantity water source.

\section{Farmer adaptations to a cropping calendar}

Indonesian farmers have applied various technologies to adapt to the season, climate and other natural phenomena both with simple or modern technology. All adaptation activity related to water management and climate conducted by the farmer was inventoried to add more information on cropping patterns for their region. This inventory will be carried out for each level of ENSO-IOD sensitivity in study area through interviews and field observation. To solve the issue of water shortage, farmers use well pumps, irrigation or pump the water from the river.

\section{RESULTS AND DISCUSSION}

\section{Rainfall variability}

In general, the rainfall in Serang, Subang and Pati districts, tended to decrease over the last 20 years (Figure 1). This downward trend may be influenced by the decline of precipitation which reached $1000 \mathrm{~mm} /$ year on dry years due to the climate anomalies in 2002/2003, 2004/2005 and 2006/2007.

\section{The impact of climate anomaly in study area}

Correlation analysis between sea surface temperature (SST) in Pacific Equator and Indian Ocean, and rainfall in study areas shows that not all rainfall stations have strong correlation with ENSO and IOD. The influences of IOD and ENSO can be seen from June to August and September to November. It coincides with the increasing SST anomaly in study regions commonly occurring around May and June. The ENSO (Nino 3.4) significantly influences the rainfall intensity in study region during June to August indicated by strong negative correlation. From September to November, ENSO and IOD increasingly influence all affected regions and it was considered as a period with strongest influence of ENSO and IOD. This was also referred to as a transition period from dry season to wet season. The influence of ENSO and IOD started to decrease between December to February and continued from March to May. This indicates that the influence of ENSO and IOD was weak.

Hendon (2003) concluded that the weak correlation between ENSO/IOD and rainfall in the wet (rainy) season addressed to the alteration of Indonesian sea surface (positive anomaly) during a transition period from dry season to wet season (from September to November to December to February). The sea surface temperature anomaly in Indonesia, is in contrast to the sea surface temperature anomaly in Pacific Ocean (center and east) and West India Ocean from June to August and September to November. However, it has the same condition from December to February and March to May.

\section{Water sources used by farmers}

The water sources used by farmers in the study area came from different sources for each planting season, during normal and dry years. The water availability in the dry year is different compared to the normal year. Farmers changed the water source in dry years as an adaptation strategy to irrigate their cultivation land as well as to avoid crop failure due to drought stress.
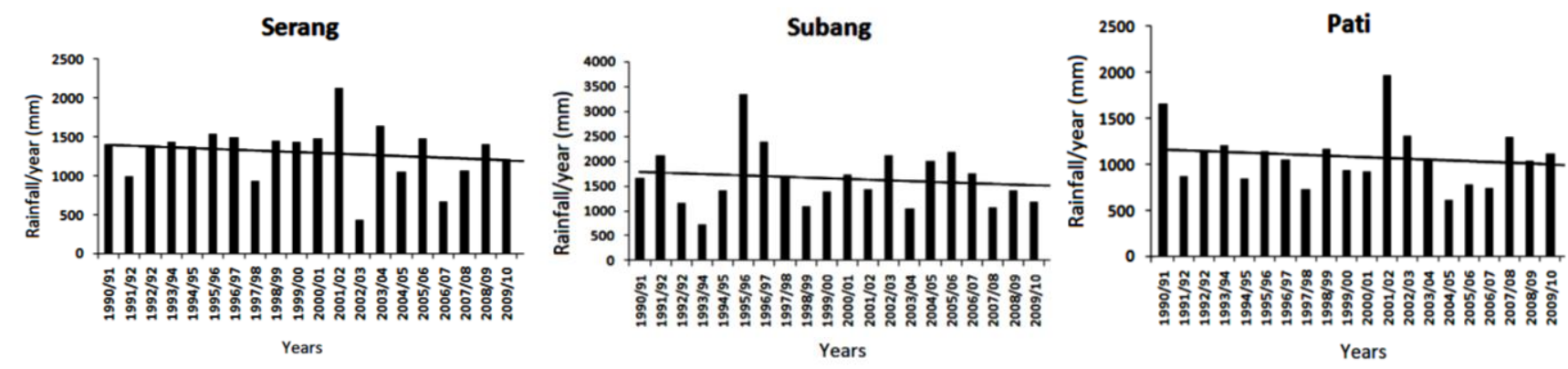

Figure 1. Downward trend of rainfall in Serang, Subang and Pati districts, Indonesia for period 1990/9991 to 2009/2010 
Table 1. The responses of farmer on water shortages at normal and dry years in Serang, Subang, and Pati districts, Indonesia during Planting Season I and Planting Season II.

\begin{tabular}{|c|c|c|c|c|c|}
\hline \multirow{3}{*}{ Irrigation type } & \multirow{3}{*}{ Water resources } & \multicolumn{4}{|c|}{ Planting season } \\
\hline & & \multicolumn{2}{|c|}{ Normal year } & \multicolumn{2}{|c|}{ Dry year } \\
\hline & & I & II & I & II \\
\hline Serang & & & & & \\
\hline \multirow{3}{*}{ Technical irrigation } & Irrigation & 100 & 100 & 100 & 60 \\
\hline & River & 0 & 0 & 0 & 30 \\
\hline & Well pump & 0 & 0 & 0 & 10 \\
\hline \multirow{3}{*}{ Semi-technical irrigation } & Irrigation & 100 & 100 & 100 & 60 \\
\hline & River & 0 & 0 & 0 & 30 \\
\hline & Well pump & 0 & 0 & 0 & 10 \\
\hline \multirow[t]{3}{*}{ Rainfed } & Rainfall & 100 & 100 & 80 & 50 \\
\hline & River & 0 & 0 & 20 & 40 \\
\hline & Well pump & 0 & 0 & 0 & 10 \\
\hline \multirow[t]{2}{*}{ Dry land } & Rainfall & 100 & 25 & 60 & 0 \\
\hline & Well pump & 0 & 75 & 40 & 100 \\
\hline \multicolumn{6}{|l|}{ Subang } \\
\hline \multirow[t]{2}{*}{ Technical irrigation } & Irrigation & 100 & 100 & 100 & 100 \\
\hline & River & 0 & 0 & 0 & 0 \\
\hline \multirow[t]{2}{*}{ Semi-technical irrigation } & Irrigation & 100 & 70 & 80 & 30 \\
\hline & River & 0 & 30 & 20 & 70 \\
\hline \multirow[t]{2}{*}{ Rainfed } & Rainfall & 100 & 70 & 60 & 0 \\
\hline & River & 0 & 30 & 40 & 100 \\
\hline \multirow[t]{2}{*}{ Dry land } & Rainfall & 100 & 70 & 60 & 0 \\
\hline & River & 0 & 30 & 40 & 100 \\
\hline \multicolumn{6}{|l|}{ Pati } \\
\hline \multirow[t]{2}{*}{ Technical irrigation } & Irrigation & 100 & 100 & 100 & 100 \\
\hline & River & 0 & 0 & 0 & 0 \\
\hline \multirow[t]{2}{*}{ Semi-technical irrigation } & Irrigation & 100 & 70 & 80 & 30 \\
\hline & River & 0 & 30 & 20 & 70 \\
\hline \multirow[t]{2}{*}{ Rainfed } & Rainfall & 100 & 70 & 60 & 0 \\
\hline & River & 0 & 30 & 40 & 100 \\
\hline \multirow[t]{3}{*}{ Dryland } & Rainfall & 100 & 70 & 60 & 0 \\
\hline & River & 0 & 30 & 30 & 70 \\
\hline & Well pump & 0 & 0 & 10 & 30 \\
\hline
\end{tabular}

Four area types in affected areas by climate anomaly in Serang district were: technical irrigation, semi-technical irrigation, rain fed and dry land (Table 1). The water availability in the normal year for these four area types was adequate. All respondents (farmers) that used semi technical irrigation in three land types could still access water from supplementary irrigation. But around $75 \%$ of farmers on dry land in the second planting season (PS II) anticipated the water shortages by using well-pump. A variety of water sources can be found during a dry year. In first planting season (PS I), the technical irrigation land can supply water adequately. However, the water shortage was still found starting from semi technical irrigation areas. Respondents used additional water from the river, $20 \%$ from semi technical irrigation land, $40 \%$ from the rainfall. On the other hand, $30 \%$ of respondents in the dry land area used water from a well-pump. During second plant season (PS II), $70 \%$ of farmers in semi-technical irrigation land and $100 \%$ of farmers in the rain fed, used water from the river. Farmers in the dry land used $60 \%$ water from the river and used $40 \%$ water from well-pump.
For the second planting season in a normal year, rainfed farmers in Serang and Pati used the well-pump as another source to irrigate their land. While in Subang, farmers just used water from rainfall as a water source for irrigation. The difference is more clear in the dry year, in which the drought affected more significant water stress in Serang and Pati than in Subang (Table 1). To solve the drought situation, the alternative irrigation scheme in Serang and Pati was more varied than in Subang.

The previous data revealed that farmers used different water sources for planting season at different characteristics of the year (normal and dry year). The water availability in the normal year was different significantly compared to the dry year. A dry year is commonly caused by the El-Nino phenomenon and a positive IOD. Alteration in finding the source of water by farmers in a dry year is an adaptation strategy to supply water to their lands as well as to protect their crops. 
The dynamical and sensitivity cropping season time in paddy field, rainfed and dry land

In general, the monsoon onset on Java Island is in September III. There were differences in both the cropping calendar and patterns for irrigated, rainfed and dry land in Serang district. Overall, the onset of planting season for irrigated lands was on November II/December II with cropping pattern rice-rice-fallow (Table 2). The onset of planting season in Serang, in general, started from November I/III to December II/III. Roughly 50\% of respondents who used technical irrigation started to plant the crops on October I/II, and the remaining started to plant the crops on November I-December II. However, $50 \%$ of respondents from the rainfed area used the onset of planting season on October III/November I and even until December II. Furthermore, in dry land, most of the farmers $(80 \%)$ cultivated peanuts on November II/III and the other $20 \%$ of respondents started to plant on October III/November I.

It was found that both the onset and crop rotation varied across the three land types. For technical irrigation, the onset of planting season is on October II/III and followed by technical irrigation. Nevertheless, in most irrigated lands, the water availability is limited, and there is even an alteration the irrigated lands to the rainfed lands with the onset November $1 / \mathrm{II}$ and the onset of dry land also in November I/II. Crop rotation rice-rice-palawija was only found in technical irrigation areas. In the irrigated and rainfed lands, the crop rotation was similar to rice-ricepalawija. On the other hand, the crop rotation for other land type was rice-rice-fallow.

Most of the farming lands in Pati district are rainfed, dry and a small part of irrigated lands. Like other districts, the onset of irrigated, rainfed, and drylands was also different. However, they have the same cropping pattern. In general, in irrigated land, the onset of planting season was on October III/February I with the crop rotation ricerice-palawija (Table 2).

\section{Farmers adaptation}

In Serang district the onset of planting season started from November II/III to December I/II. Around $70 \%$ of respondents in technical irrigation lands planted the crop on November II/III. Furthermore, around $20 \%$ of respondents cultivated the plants on November III/December I. The rest of the respondents $(10 \%)$ had planting season on December I/II. Moreover, in the rainfed lands, many of the respondents $(80 \%)$ planted the crops on January I/II and the rest was on January II/III. In drylands, $70 \%$ of respondents started to plant palawija, especially peanut and maize on November I/II and around $30 \%$ on November II/III (Figure 2).

For the irrigated areas in Subang District, most respondents $(80 \%)$ determined the onset of planting season on October II/III and the remaining $20 \%$ on October III/November I. Moreover, the onset of planting season of $70 \%$ of respondents in semi-technical irrigation areas was on October II/III and for $30 \%$ on November II/III. While for dry land, the onset of $50 \%$ of respondents was executed on November I/II and the rest was on November II/III (Figure 3).

The onset of planting season in Pati district was on October II/III applied by around $80 \%$ of farmers in irrigated land. The remaining respondents were on October III/November I and November I/November II. In the rainfed areas, the onset of planting season for $70 \%$ of respondents in Pati Districts was on November/November, $20 \%$ on November I/II and $10 \%$ on December I/II. Whereas in dry land, around $80 \%$ of farmers cultivated palawija (secondary crop) mainly maize on November I/II and the others on November III/December I (Figure 4).

For all cases of study areas in Pati, Subang, and Serang, farmers in the irrigated lands planted earlier 2-4 decades than in farmers in another land type. In general, farmers in semi-technical irrigation in Subang district, don't have to access the irrigation water. Therefore, they use rain fall and well pump to irrigate their land.

The differences in water availability in Serang and Subang districts can be represented by the variation of crop rotation. There were significant differences in crop rotation patterns, especially in the rainfed areas. Crop rotation in Serang district was dominated by rice cultivation twice a year while in Subang district was dominated by three-time cultivation Rice-Rice-Palawija (Table 3).

Table 2. Onset and crop rotation in different site/land types

\begin{tabular}{lll}
\hline Land type & Onset & Planting rotation \\
\hline Serang & Nov II - Dec II & Rice-rice-fallow \\
Irrigation & Jan I - Jan III & Rice-palawija crops-palawija crops \\
Rainfed & Jan I - Feb I & Palawija crops-palawija crops-fallow \\
Dryland & & \\
Subang & Oct II - Nov I & Rice-rice-palawija crops \\
Technical irrigation & Nov I - Nov II/III & Rice-rice-fallow \\
Semi technical irrigation & Nov I - Nov III & Rice-rice/palawija crops/fallow-fallow \\
Rainfed & Nov I - Nov III & Palawija crops-palawija crops/fallow-fallow \\
Dryland & & \\
Pati & Oct II - Nov II & Rice-rice-fallow \\
Technical irrigation & Oct II - Nov II & Rice-rice-fallow \\
Semi technical irrigation & Nov I - Dec II & Rice-rice/palawija crops/fallow-fallow \\
Rainfed & Nov I - Dec I & Palawija crops-palawija crops/fallow-fallow \\
Dryland &
\end{tabular}



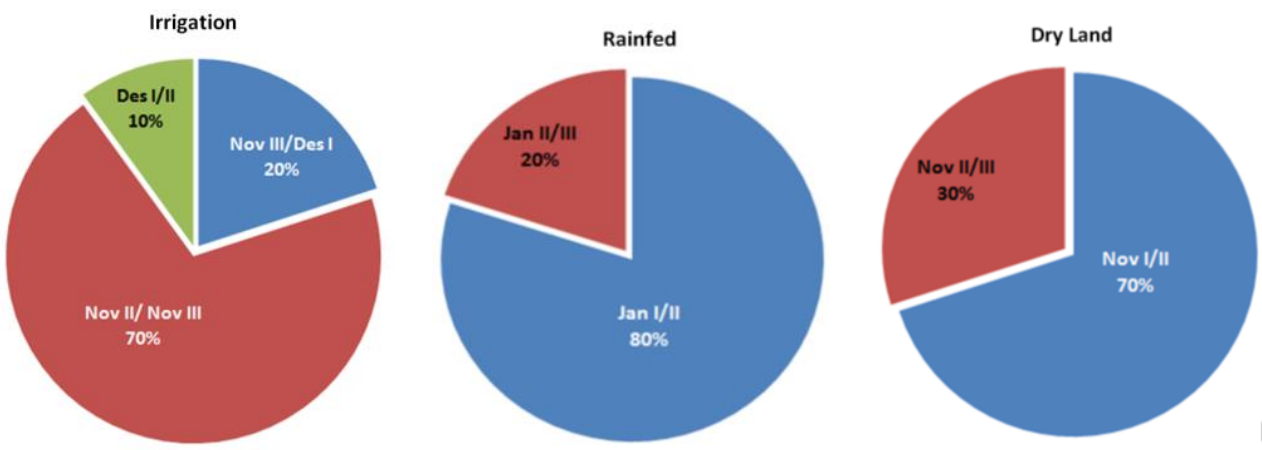

Figure 2. The existing onset of planting season in Serang district, Banten Province, Indonesia
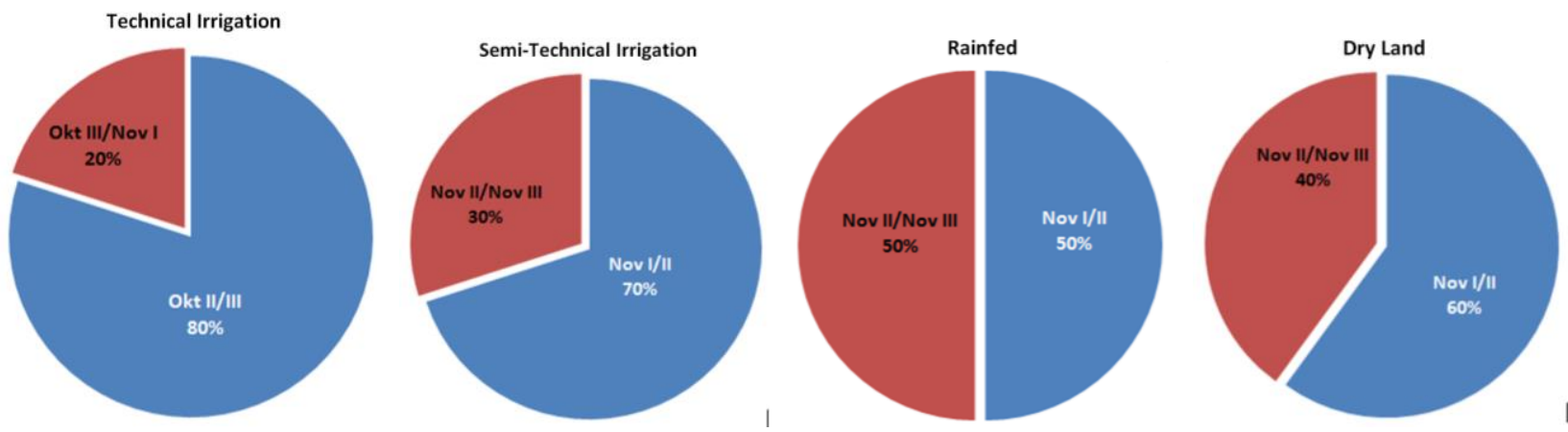

Figure 3. The existing onset of planting season in Subang district, West Java Province, Indonesia
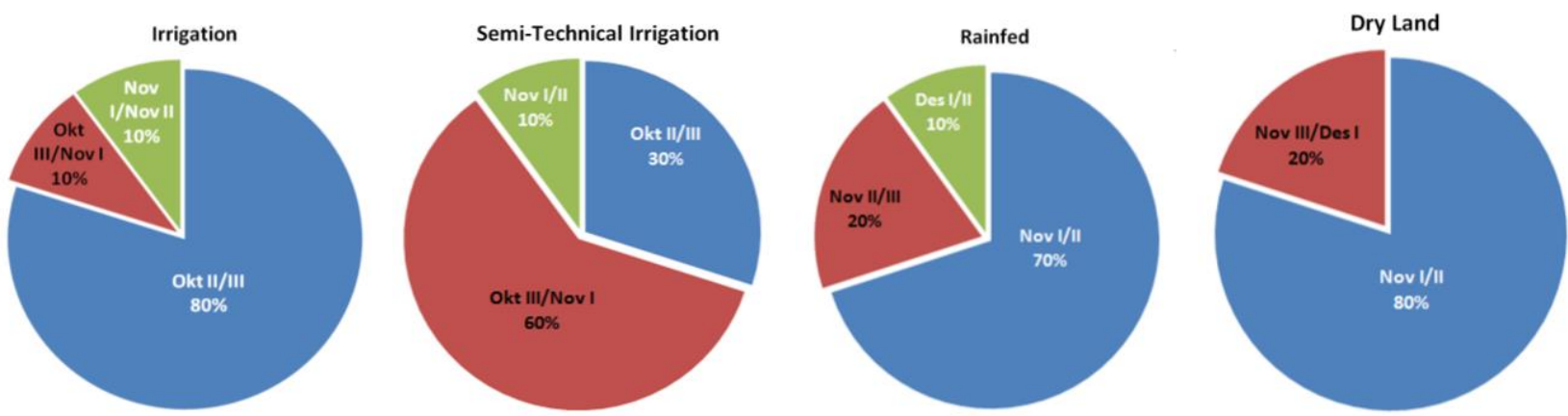

Figure 4. The existing onset of planting season in Pati district, Central Jawa Province, Indonesia

The irrigation management in Serang and Subang districts is better than other study areas since the location of this district is near the Jatiluhur reservoir, West Java, Indonesia. This reservoir is one of irrigation sources for the many surrounding farming areas. Therefore, water supply for technical irrigation was not influenced by the climate anomaly. The same case was also like the irrigated areas in Pati district. The alteration of crop rotation was conducted by farmers in rainfed lands and dry lands in Serang districts. In Subang, the crop modification was found on the technical irrigation, rainfed and dryland areas, while in Pati the plant rotation was found in semi technical irrigation, rainfed and dryland areas.

In the third planting season (PS III) the cropping index is decreased and no crop farming in almost all agriculture lands. For PS I in a dry land, the farmer generally didn't grow rice but palawija (secondary crop). In Serang for the same planting season, farmers cultivated peanut and maize, whereas, in Subang and Pati, farmers planted corn.

In a dry year, farmers in the study area dealt with the dry condition in several ways (Table 4). Most of the farmers try to irrigate their land from other water sources or delay the onset of planting season. Roughly $75 \%$ of farmers in Serang in irrigated land anticipated drought conditions by delaying the onset for around two weeks and $25 \%$ of farmers don't postpone the onset since water is still available. In the rain fed areas, $65 \%$ of farmers decided to find another water source and $35 \%$ agree to postpone the onset for even more than four weeks. Moreover, in dryland during dry conditions, around $30 \%$ of farmers pump water 
from the river to irrigate their land but $70 \%$ of farmers adapt to that situation by delaying their onset.

In Subang, around $80 \%$ of respondents in irrigation areas decided to plant, and $20 \%$ of respondents delayed their onset approximately two weeks. Farmers in irrigated lands adapt to dry conditions by delaying the onset for about two weeks instead of finding the other water source. However, in technical irrigation 4-5, 85\% of farmers delay the onset two weeks to deal with drought, and $20 \%$ try to find other water sources from the river. In the rain fed, $65 \%$ of farmers decide to find other water origin and $35 \%$ delayed the onset for more than four weeks. In dryland, $30 \%$ of farmers pump water from a river, and $70 \%$ delayed the onset.
In Pati, $75 \%$ of farmers in irrigated land anticipate drought by delaying the onset of planting season approximately two weeks and $25 \%$ decide to plant as water is still available. In technical irrigation, the farmer decides to delay the onset two weeks while waiting for water supply. But in semi technical irrigation, most of the farmers adapt to dry conditions by delaying the onset two weeks, leaving $20 \%$ of farmers to pump water from a river. In the rain fed, $65 \%$ of farmers try to find other water sources and $35 \%$ delay their onset four weeks. In dryland, $40 \%$ of farmers pump water from the river and $30 \%$ decide to delay the onset (Table 4).

Table 3. Farmer's response to adjust the crop rotation

\begin{tabular}{|c|c|c|c|c|c|c|c|c|c|}
\hline \multirow[b]{2}{*}{ Irrigation type } & \multicolumn{4}{|c|}{ Normal year $(\%)$} & \multicolumn{5}{|c|}{ Dry year (\%) } \\
\hline & $\begin{array}{c}\text { Rice- } \\
\text { rice- } \\
\text { palawija }\end{array}$ & $\begin{array}{l}\text { Rice- } \\
\text { rice }\end{array}$ & $\begin{array}{c}\text { Rice- } \\
\text { palawija- } \\
\text { palawija }\end{array}$ & $\begin{array}{c}\text { Palawija- } \\
\text { palawija }\end{array}$ & $\begin{array}{c}\text { Rice- } \\
\text { rice- } \\
\text { palawija } \\
(\%) \\
\end{array}$ & $\begin{array}{l}\text { Rice- } \\
\text { rice }\end{array}$ & $\begin{array}{c}\text { Rice- } \\
\text { palawija- } \\
\text { palawija }\end{array}$ & $\begin{array}{l}\text { Palawija- } \\
\text { palawija }\end{array}$ & $\begin{array}{c}\text { Rice/ } \\
\text { palawija }\end{array}$ \\
\hline \multicolumn{10}{|l|}{ Serang } \\
\hline Technical irrigation & 0 & 100 & 0 & 0 & 0 & 60 & 40 & 0 & 0 \\
\hline Semi technical irrigation & 0 & 100 & 0 & 0 & 0 & 60 & 40 & 0 & 0 \\
\hline Rainfed & 0 & 1 & 100 & 0 & 0 & 10 & 40 & 30 & 20 \\
\hline Dryland & 0 & 1 & 0 & 100 & 0 & 0 & 0 & 20 & 80 \\
\hline Subang & 0 & 0 & 0 & 0 & 0 & 0 & 0 & 0 & 0 \\
\hline Technical irrigation & 100 & 0 & 0 & 0 & 20 & 80 & 0 & 0 & 0 \\
\hline Semi technical irrigation & 0 & 100 & 20 & 20 & 0 & 20 & 80 & 0 & 0 \\
\hline Rainfed & 0 & 60 & 0 & 100 & 0 & 0 & 60 & 40 & 0 \\
\hline Dryland & 0 & 0 & 0 & 0 & 0 & 0 & 0 & 40 & 60 \\
\hline \multicolumn{10}{|l|}{ Pati } \\
\hline Technical irrigation & 100 & 0 & 0 & 0 & 20 & 80 & 0 & 0 & 0 \\
\hline Semi technical irrigation & 0 & 100 & 0 & 0 & 20 & 80 & 0 & 0 & 0 \\
\hline Rainfed & 0 & 60 & 20 & 20 & 0 & 0 & 50 & 50 & 0 \\
\hline Dryland & 0 & 0 & 0 & 100 & 0 & 0 & 0 & 30 & 70 \\
\hline
\end{tabular}

Table 4. The farmers responses to dry conditions in different land type

\begin{tabular}{|c|c|c|c|c|}
\hline \multirow[b]{2}{*}{ Land type } & \multicolumn{4}{|c|}{ Farmer respondent (\%) } \\
\hline & Planting & $\begin{array}{c}\text { Finding other water } \\
\text { sources }\end{array}$ & Delayed 2 weeks & Delayed more 4 weeks \\
\hline \multicolumn{5}{|l|}{ Serang } \\
\hline Technical irrigation & 25 & 0 & 75 & 0 \\
\hline Semi technical irrigation & 0 & 25 & 75 & 0 \\
\hline Rainfed & 0 & 65 & 0 & 35 \\
\hline Dryland & 0 & 30 & 0 & 70 \\
\hline \multicolumn{5}{|l|}{ Subang } \\
\hline Technical irrigation & 80 & 0 & 20 & 0 \\
\hline Semi technical irrigation & 0 & 20 & 85 & 0 \\
\hline Rainfed & 0 & 65 & 0 & 35 \\
\hline Dryland & 0 & 70 & 0 & 30 \\
\hline \multicolumn{5}{|l|}{ Pati } \\
\hline Technical irrigation & 25 & & 75 & 0 \\
\hline Semi technical irrigation & & 20 & 80 & 0 \\
\hline Rainfed & & 65 & 0 & 35 \\
\hline Dryland & & 40 & 30 & 30 \\
\hline
\end{tabular}


Since dry conditions cannot be avoided, farmers adapt to this situation by finding other water source or by delaying the onset of planting season and other activity to reduce the damage and loss caused by drought. It found that the response of farmers in different locations was varied. One reason for this is that the water availability for each site is different.

In general, in Subang farmers decide to find other water sources both in irrigation land or in the rain fed land. But several respondents delay the onset for about two weeks because the water source was far from their land. Unlike farmers in Subang, farmers in Pati in both technical or semi-technical irrigation delay their onset approximately two weeks instead of finding other water sources. This activity can be seen clearly in PS II in a dry year. In the rain fed land, the response of farmers is different significantly than the response in irrigated land. In the rain fed, the farmer decides to find other water sources instead of delaying the onset, and most of the farmers plant twice a year. The other water source that they used is pump water from the river. To do so, they must pay an extra cost. Those that delay their onset roughly one month are those farmers who plant only once a year.

In conclusion, the farmers in affected areas due to climate variability could adapt to shift the onset of planting season. Farmers in irrigated lands change their onset around 2-4 ten-days period becomes October II - December II, in rainfed area around 4-6 ten-days period becomes November I - January III and in dryland around 6-8 tendays period from November II - February I. The cropping pattern rice-rice-palawija/fallow was applied in irrigated land, rice-rice/palawija/fallow-fallow in rainfed and palawija-palawija/fallow-fallow in dryland. In irrigated land, $75-80 \%$ of farmers decide to delay the onset two weeks while waiting for water supply. In rainfed areas, $65 \%$ of farmers try to find other water sources and $35 \%$ of them delay their onset four weeks. In dryland, 30-70\% of farmers pump water from the river and $30-70 \%$ decide to delay the onset more than four weeks. Adaptation programs to deal with climate extremes in Serang and Pati vary more than in Subang. In Serang and Pati, during first planting season, farmers applied irrigation roughly 20\%-30\% pump water from river and during second planting season, in Pati farmers use water from well pump and even in Serang reach $100 \%$.

\section{ACKNOWLEDGEMENTS}

We would like to acknowledge the valuable funding support given by Indonesian Agroclimate and Hydrology Research Institute, Bogor, Indonesia. We would also like to express our gratitude for the many constructive comments provided by Dr. Haris Syahbuddin.

\section{REFERENCES}

Apriyana Y, Siburian IM. 2014. Farmers Strategy Responding to Climate Variability in Rice Production Centers region of West Java. Proceedings of the National Seminar on Food Sovereignty and Agriculture. Results of Socio-Economic Research, Faculty of Agriculture, UGM, Yogyakarta.

Apriyana Y. 2011. Determination of Rice Cropping Calendar based on the ENSO (El Niño Southern Oscillation) and IOD (Indian Ocean Dipole) Phenomena in Monsoonal and Equatorial Regions. [Dissertation]. IPB Bogor.

Ashok K, Guan Z, Yamagata T. 2001. Impact of the Indian Ocean Dipole on the relationship between the Indian monsoon rainfall and ENSO. Geophys Res Lett 28: 4499-4502.

Behera SK, Luo JJ, Yamagata T. 2008: The Unusual IOD Event of 2007, Geophys Res Lett 35: L14S11, DOI:10.1029/2008GL034122.

D’Arrigo R, Wilson R, Palmer J, Krusic P, Curtis A, Sakulich J, Bijaksana S, Zulaikah S, Ngkoimani O. 2006. Monsoon drought over Java, Indonesia during the past two centuries. Geophys Res Lett 33: L04709, DOI:10.1029/2005GL025465.

Hansen JW, Mason SJ, Sun LA. 2011. Tall Review of seasonal climate forecasting for agriculture in sub-Saharan Africa. Exp Agric 47: 205240.

Koesmaryono Y, Las I, Aldrian E, Runtunuwu E, Syahbuddin H, Apriyana Y, Ramadhani F, Trinugroho W. 2008. Report of Activities. Sensitivity and Dynamics Parameters Against Rice Planting Calendar ENSO (El Nino Southern Oscillation) and IOD (Indian Ocean Dipole) in monsoon and Equatorial Region. KKP3T report. Research MOAIPB, Bogor.

Las I, Unadi A, Subagyono K, Syahbuddin H, Runtunuwu E. 2007. Atlas Cropping Calendar in Java. Scale 1:1.000.000 and 1:250.000. Indonesian Agroclimate and Hydrology Research Institute, Bogor.

Las I, Pramudia A, Runtunuwu E, Setyanto P. 2011. Anticipation of climate change in security national rice production. J Agric Innov Dev 4(1): 76-86.

Linderholm HW. 2006. Planting season changes in the last century. Agric For Meteor 137 (1-2): 1-14.

Naylor RL, Battisti DS, Vimont DJ, Falcon WP, Burke MB. 2007. Assessing the risks of climate variability and climate change for Indonesian rice agriculture. Proc Natl Acad Sci USA 104: 7752-7757.

Naylor RL, Falcon WP, Rochberg D, Nikolaswada. 2001. Using El Niño/Southern Oscillation Climate Data to predict rice production in Indonesia. Clim Change 50: 255-265.

Runtunuwu E, Ramadhani F, Kharmilasari. 2007. Petunjuk Teknis Penggunaan Perangkat Lunak Neraca Air Tanaman WARM-2.0 (Water Agroclimate Resources Management Ver 2.0) Indonesian Agroclimate and Hydrology Research Institute, Bogor. [Indonesian] 